\title{
DETERMINANTS OF INVESTMENT BEHAVIOR: UNITED STATES RAILROADS, 1872-1941*
}

\author{
Jan Kmenta \\ and \\ Jeffrey G. Williamson
}

\section{Introduction}

$\mathrm{T}$ $1 \mathrm{HE}$ major purpose of this work is to improve our understanding of investment behavior in one important industry, the railroad industry, over some seven decades of American history. This investigation makes one important departure from most investment studies. The primary emphasis is to isolate the likely changes in investment behavior which occur as the industry passes through a fairly predictable set of institutional and growth phases. The basic thesis, explicitly tested in the material that follows, is that the determinants of investment depend critically upon the phase of the industry's life-cycle. For example, the relative importance of capital costs for firm expansion may assume quite different proportions for a mature industry than for one beginning adolescent growth. In the same fashion, the relative importance of internal profits as a source of funds is likely to vary with the position of the industry in its life-cycle. In addition, the speed of response to evidence of profitability may change with the age of the industry, its growth, and its ability to absorb risk. We present below an extensive description of expected shifts in the railroad industry's investment behavior over time.

The reasons for selecting the railroads should be evident. This is one of the few American industries for which we have considerable investment data relating to the major portion of its complete life-cycle. Recently, information covering the period since 1870 became available with the appearance of Ulmer's impressive volume [21]. Ulmer has assembled annual estimates of gross and net investment, output, and capital stock, all in constant and current prices. Although Fishlow has recently pointed

* This topic was initially suggested some time ago by Moses Abramovitz. We express our thanks to the Social Systems Research Institute of the University of Wisconsin for their support of the study and to Leonard Weiss and Allen Kelley for their helpful comments. out some weaknesses in Ulmer's data, ${ }^{1}$ it appears to us unduly cautious to abstain from using this wealth of historical information while awaiting future revisions.

This introductory background gives rise to the following plan for this paper. Section II reviews and classifies the historical background of railroad development over our period of interest. In that section we develop and define the life-cycle stages which we use in the tests themselves. Section III presents the models of investment behavior which we attempt to test in section IV. Section V follows with a summary of the study's results.

\section{Stages of Growth}

Ulmer's estimates of railroad investment and output are an obvious aid in defining the industry's growth stages over the late nineteenth and early twentieth centuries. Concentrating our attention on periods of peak investment rates, it would appear that net railroad investment increased by increasing amounts between 1840 and 1857. Between the approximate dates 1857 and 1881, net capital formation increased by decreasing amounts while the subsequent period 1881-1931, was one of declining net capital formation but at levels which were still typically positive. After 1931, the level of net railroad investment was generally negative. Furthermore, gross capital formation most certainly reached an all-time high in the preWorld War I decade.

We are also able to quantify our impressionistic notions concerning the relative importance of the railroads in total aggregate demand. The output of the railroads as a share of gross national product reached its maximum during the period of intensive World War I use (19101920). At that time the share was as large as

\footnotetext{
${ }^{1}$ Professor Fishlow's remarks were made at the September 1963 Conference on Research in Income and Wealth and can be found in his as yet unpublished manuscript [10].
} 
eight or nine per cent [21, p. 90]. Gross investment, however, achieved a peak level of relative importance much earlier. During the years 1870-1895 the railroads accounted for something like 13 per cent of aggregate gross investment. That share declined to about seven per cent over the period 1890-1914 and then to approximately three per cent over the decades 1920-1940 [22, p. 138].

A detailed examination of railroad investment reveals severe short-run fluctuations. More important, ". . . well-known long cycles in railroad construction ..." are exhibited over these 70 years [1, p. 238]. There appear to be approximately three of these violent swings between the dates 1872 and 1941 and they suggest a possible separation of the period into life-cycle stages (see figure 1). Tentatively, we decided on the following separation:

Gross and Net Capital Expenditures in United States RaIlRoadS (1929 \$) : 1870-1941.

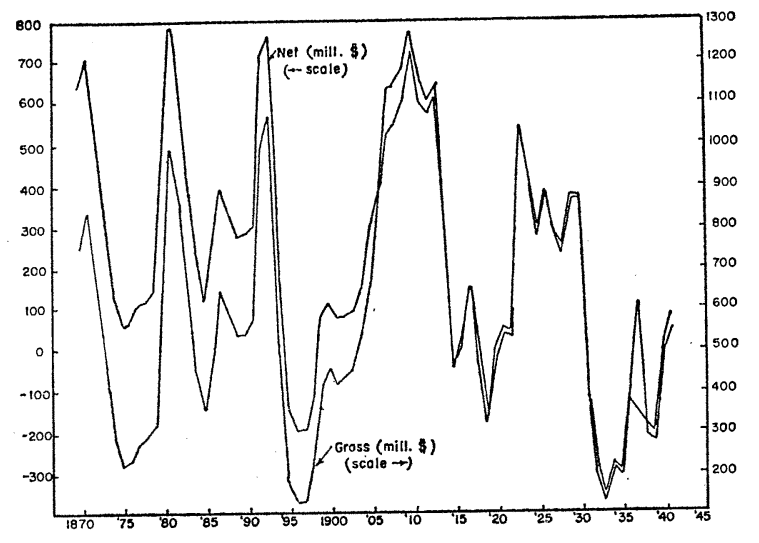

an early period of adolescence, 1872-1895, a middle period of maturity, 1896-1914, and, discarding the unusual war years of governmental control a final period of senility, 1922-1941.2 The fortuitous nature of the long swing breaks in 1896 and World War I impose our terminal years, but more evidence is required to justify our assumption of distinct phases in the industry's life-cycle. We have already reviewed some of the evidence to support our choice. To summarize, in the early period of adolescence the

\footnotetext{
${ }^{2}$ It is worth noting that Koyck [17], in a study of investment in freight cars, also distinguished between a "period of expansion" (1894-1915) and a "period of contraction" (1920-1939).
}

railroads are still growing at a pace exceeding the average for the economy as a whole; in the middle period of maturity the industry, while still expanding, is no longer a dynamic sector relative to the rest of the economy; in the latter period of senility the industry eventually undergoes a general absolute decline.

The changing regional nature of American railroad investment offers additional support for our choice of discontinuous stages. One distinctive aspect of the 1870's and 1880's is that these are the last decades in which extensive railroad investment was taking place. After the mid-1890's, the continental railroad network was more or less complete. "Much of the railroad building [1879-1881] consisted of completing the main lines of roads which had been stopped by the panic of 1873 . The Northern Pacific, for instance, completed its route" $[9$, p. 115]. Even at that, the last decade of our early period of adolescence is a transitional one:

Even more important [during the 1880's] was the construction of feeders and branches for parent lines .... For the most part, therefore, construction was undertaken not by new enterprises but by established lines to which it was becoming more of a routine operation than a venture into innovation $[9$, p. 116].

This suggests another important life-cycle distinction. In the early period, railroad expansion in new regions - and to some extent the rate of new firm entrance - was still significant although it was of declining importance. In contrast, the era of consolidation, merger, and restriction on new firm entry reached real significance in the first decade of the twentieth century. This may be in part related to the exhaustion of possibilities for extensive single track mileage and the disappearance of unexploited regions. In any case, by 1900 the five dominant systems - the Morgan-Hill, Harriman, Pennsylvania, Vanderbilt, and GouldRockefeller systems - controlled about onehalf of the 258 million miles in operation at that time [2, p. 170].

In addition, the sharp changes in the methods used by the railroads in securing financing suggest distinctive stages. Only about 2.4 per cent of railroad gross investment was financed by retained profits and depreciation charges in the 1880 's, a fact typical of a still young and rapidly growing industry with large capital require- 
ments per firm unit. This proportion increased somewhat to 9.5 per cent for the period 18931907 but then jumped sharply to 42.6 per cent during 1907-1916. By the 1920's, the transition to internal financing was apparently almost complete since the share reached 94.8 per cent during the decade 1921-1930 and 97.4 per cent during the 1930's. The abrupt secular shift from external to internal financing is just as evident if one examines the ratio of retained profits to total sources. By the 1907-1916 period the figure had reached 29.7 per cent, and in the decade 1921-1930, 50.8 per cent [21, Table 46, p. 150].

The long-run transition between bond and stock issues as a method of external financing is less dramatic, but still significant. During the decade of the 1880 's, about 56 per cent of total new railroad security issues (excluding refunding) was in the form of bonds. During the immediate pre-World War I era, 1907-1916, that proportion had risen to 63.2 per cent, while during the 1920's it was as high as 71.5 per cent [21, Table 46, p. 150].

It should also be recognized that the structure of investment itself underwent significant change over the period 1872-1941. Although empirical verification is impossible, most of the current research on American railroads suggests that the relative importance of rolling to fixed stock remained almost constant until the very end of the nineteenth century. At that time, and throughout the 1920's and 1930's, rolling stock increased in importance as a share of net railroad investment. Furthermore, the significance of main track declined as the industry progressed, revealing the increasingly intensive nature of railroad investment. The increase in main track in the 1870's amounted to as much as 80 per cent of total mileage added. In the 1880's the share was approximately 70 per cent, but by the 1899-1909 decade, when the industry matures, that ratio had fallen to only seven per cent [10, Table 2 , p. 15].

A final comment concerns the role of governmental interference. As far as the federal land grants are concerned, they should have little influence upon investment behavior during our period of study since the last federal railroad land grant was authorized on March 3, 1871. With regard to legislation over the railroads, neither state nor federal control really became effective until a few years prior to the first World War. The railroad's stage of maturity is, then, a transitional one between the stage of adolescence, relatively free of intervention, and the period of senility, one of severe governmental control inaugurated decisively with the Transportation Act of 1920.

\section{Hypotheses}

Of particular interest to us is a study of United States railroad investment carried out by Klein [16] some years ago for the period 1922-1941. Klein constructed and estimated a large number of regression models and concluded that the most satisfactory results were given by the following two relationships:

$$
\begin{array}{rrr}
I_{t}^{G} & =1596+0.75 \pi_{t-1}-51 i_{t}-0.14 K_{t-1} \\
(0.08) & (18) \quad(0.02) \\
+\hat{u}_{t}, & \bar{R}^{2}= & 0.903,
\end{array}
$$

or

$$
\begin{gathered}
I_{t}^{G}=2647+0.88 \pi_{t-1}-69 i_{t-1}-0.20 K_{t-1} \\
(0.09) \quad(15) \quad(0.02) \\
-301 q_{t-1}+\hat{u}_{t}, \quad \bar{R}^{2}=0.941 \\
(128)
\end{gathered}
$$

where

$I^{G}=$ gross expenditure on road and equipment in 1910-1914 prices,

$\pi=$ net railway operating income before depreciation, deflated by a railroad construction cost index,

$i=$ average yield on new railroad bonds (percentage),

$q=$ price index of railroad capital goods, 1910$1914=100$, and

$K=$ end of year stock of fixed capital in road and equipment in 1910-1914 prices.

Although there are some difficulties concerning interpretation, ${ }^{4}$ Klein's comprehensive effort to explain the variations in railroad investment during the inter-war period is impressive

\footnotetext{
${ }^{3}$ Furthermore, ". . . the entire federal outlay and most of the state and local commitments were made in the few years before $1873 \ldots$ in the wave of new investment that brought the total of railroad capitalization in 1890 to more than $\$ 10,000,000,000$, public agencies contributed no more than a negligible fraction [12, p. 27.1]."

${ }^{4}$ See Eisner and Strotz [8, pp. 147-149].
} 
and the models appear to us to deserve further testing. At the time of his inquiry the new and presumably improved set of data compiled by Ulmer was not available. If Klein's models for the period 1922-1941 are appropriate and if Ulmer's data are indeed superior to the data used by Klein, ${ }^{5}$ then the re-estimated equations should be at least as satisfactory as his original estimates.

A further test of Klein's models arises from our emphasis upon life-cycle investment analysis. The central theme of our study is that investment in the railroads can best be explained by models which differ according to the historical stage of the industry's growth. A competing hypothesis would assert that the same model is applicable to every stage of the industry's life-cycle. Since Klein's models appear to be quite successful explanations of investment behavior during the inter-war period, they should be suitable for testing the "single model" hypothesis. If his models withstand this test, the result would be inconsistent with the hypothesis of differential behavior over an industry's life-cycle.

On the other hand, if a single investment model is inappropriate for all stages of the industry's lifetime, we must be prepared to develop alternative models for each of these industry stages. As suggested above, logical distinction can be made between the period of adolescent development, that of mature growth, and that of stagnation or decline. Thus we need three, presumably different, stage-ofgrowth models (to be referred to as "SG models") to describe the time pattern of aggregate railroad investment.

Let us first consider the process of investment determination in the adolescent stage. In this period, from 1872 to the mid-1890's, entry of firms into the industry is relatively frequent. New railroad investment is carried out in part by firms already in the industry (predominantly in the older Eastern and Midwestern regions), and in part by firms entering the industry for the first time (predominantly in the newer Southern and Western regions). The "old" firms operate with a given quantity of fixed capital constructed in past railroad booms

\footnotetext{
${ }^{5}$ Klein's gross investment figures come from [14, p. 35]. His cost index is taken from [15].
}

and/or in expectation of future long-run demands. The level of existing fixed and rolling stock might be considered optimal for a given anticipated demand for output, which may include a certain degree of planned excess capacity. $^{6}$ If the demand for transportation services on existing railroads increases, the rolling and fixed stock will be insufficient in relation to demand. Profits, both in absolute levels as well as in relation to existing stock, will increase providing there exists some excess capacity. If a firm is already at full capacity, further increase in demand will be met only with increases in per unit costs. Unless railroad rates are increased, profits will cease to grow and may even decline. The firm may offset these deleterious effects by charging higher rates for transportation services and/or by expanding fixed capital. The first course of action - increase in price - is less likely to be taken in theory and was avoided in fact. Prices of railroad services were not typically flexible in the short-run, and perhaps more important, excessive rates invited competition as well as public reaction. ${ }^{7}$ To pursue this simulation, "old" firms may not wait until all excess capacity is eliminated but may undertake new investment as the point of full capacity is approached. It appears then that the investment decision of firms already in the industry is likely to be based on the relationship of the existing stock of capital to that which would be optimal under prevailing output conditions.

The completeness of the capital stock adjustment model requires two further assumptions. First, it must be assumed that firms expect the changes in demand to be permanent, otherwise there would hardly be any rational basis for changing the size of capital stock in response to past changes in demand. This is not an unreasonable assumption for the 1870's and 1880's - a stage characterized by strong secular increases for railroad services. Second, this framework assumes a relative absence of invest-

\footnotetext{
${ }^{6}$ The romantic case in traditional history texts, but apparently of little quantitative importance after 1870 and relative to American railroad investment as a whole, is the developmental road which is constructed in anticipation of future urban growth and interregional trade. See, for example. Cootner [5].

${ }^{7}$ Very early in their history, the railroads reveal a desire to restrict ". . . competition to certain areas and to service rather than price." Cochran $[4$, p. 160].
} 
ment attributable to cost-reducing innovations. There is some qualitative evidence which suggests that cost reducing innovations were not typically a motivating force per se but that such improvements as the steel rail, treated ties, Diesel engines and automatic couplers were utilized only when old equipment was being replaced or when new demand-induced investment was undertaken. ${ }^{8}$

A final question remains concerning the role of the rate of interest in investment decisionmaking. In equilibrium, the marginal efficiency of capital of the last project will just equal the prevailing rate of interest. In the early stage of industry growth, however, disequilibrium is more likely in the sense that the long-run marginal efficiency of the last project exceeds the interest rate by a considerable margin. Under these conditions, fluctuations in the rate of interest (or some alternative measure of money capital costs), unless very marked, are likely to be largely irrelevant.

With respect to the lag structure, the reactions of management are likely to be relatively slow. Early railroad development took place in an era of inefficient communication systems, administrative procedures, and capital raising methods. Furthermore, given the relative growth of the industry in the 1870's and 1880's as compared to the 1920's, the composition of new investment was more of the long gestation type. A two-year lag would then appear to be appropriate in the earlier period since the facts bearing upon investment decisions were likely to have become known only in the next year,

\footnotetext{
${ }^{8}$ Cootner takes this view in a recent article [5]. "Even with the steady, gradual improvement in the economics of producing rail transport, the impetus to the eventual integration of the railroad invention into United States economic life came primarily from demand" [5, p. 484]. Further, he states "It is clear . . . that I find no evidence anywhere in the process of railroad development of anything that would constitute a technical jump great enough to generate an exogenous railroad boom .... The railroads experienced constant technical improvement - larger locomotives, bigger and better designed rails, better brakes, substitution of coal for wood as fuel, etc. - but there is no record of . . . discontinuous change. ..." [5, pp. 504-505].

Commenting on the pre-1890's Cochran says that "This meant, in turn, that the readiness with which the executive installed a new invention or method was related to the immediate outlay of capital required and the business situation ... downturns of the business cycle often forestalled capital expenditures for new devices, regardless of their promise" $[4$, p. 144].
}

and the investment decision itself probably did not become effective until the year after. ${ }^{9}$

In addition to investment carried out by firms already in the industry, in boom conditions new firms will tend to enter and establish a fixed capital base. The basic difference between the "old" and "new" firms is the element of risk which is considerably greater for new entrants in the less developed regions. These may have to be assured of fairly high profits before they may be able to raise the necessary finance. The firmest basis for estimates of future returns on capital is the profit experience of the existing firms. New firms will be induced to enter if the existing firms are exhibiting high profit rates, and especially if profits are showing an upward trend. Here again, because of the time needed for decision-making, capital raising and construction, a two-year lag is likely to be most appropriate. ${ }^{10}$

If we combine the two types of investment behavior into a single model and assume linearity, we can express the postulated relationship as

$$
\begin{aligned}
& I_{t}=a_{0}+a_{1}\left(\delta_{1} X_{t-2}-K_{t-2}\right)+a_{2}\left(\pi^{*} / K\right)_{t-2} \\
& \left.\quad+a_{3}\left(\pi_{t-1}^{*}-\pi_{t-2}^{*}\right)+u_{t}, \quad \text { (SG } 1\right)
\end{aligned}
$$

where

$$
\begin{aligned}
I & =\text { net investment } \\
X & =\text { output, } \\
K & =\text { capital stock at the beginning of each } \\
& \text { period, } \\
\pi^{*}= & \text { net operating income after depreciation, } \\
& \text { and } \\
u= & \text { random disturbance. }
\end{aligned}
$$

The constant term, $a_{0}$, is included as a provision for the possible existence of "autonomous" investment. The coefficient $a_{1}$ is the reaction coefficient which reflects the speed of adjustment to a capital stock disequilibrium on the part of entrepreneurs while $\delta_{1}$ is a measure of the "normal" capital-output ratio and $\left(\delta_{1} X\right)$ is then the size of capital stock which is con-

\footnotetext{
${ }^{9}$ Tinbergen [20], in his study of United States investment in rolling stock (1896-1913), used a lag of 1.5 years. This is reasonably consistent with our choice of a two-year lag since we are limited by annual data and are concerned with both fixed and rolling stock.

${ }^{10}$ Ideally, a more powerful test of these theories would be the independent examination of investment behavior of new versus old firms or of investment in new versus old regions. Unfortunately, data are not yet available for such regional disaggregation.
} 
sidered by entrepreneurs as appropriate under output conditions given by $X .{ }^{11}$

Let us now consider the second stage of the railroad industry's life-cycle. This stage (18961914) is characterized by expansion and consolidation of the existing firms since there is now very little room for opening up of new territories, and thus only a limited opportunity for new entries. The industry undergoes considerable re-organization to conform to the new pattern of market distribution, mergers occur at a peak rate, and profits run at a relatively high and secularly stable level. Under these new environmental conditions, "old" railroad companies still tend to undertake new investment if output outruns the existing rolling and fixed stock. Disinvestment, as in the mid1890's, may even take place if the existing capital stock is abundant relative to output. Since new entries are rare, the profit variables are less likely to be relevant. Investment determination in the second stage of the industry's life-cycle - its middle age - is then hypothesized to be:

$$
I_{t}=\beta_{0}+\beta_{1}\left(\delta_{2} X_{t-2}-K_{t-2}\right)+u_{t},
$$

where the variables are defined as in the previous model.

The final stage of the industry's life-cycle, the period of senility (1922-1941), is one of slow growth or even decline in the face of highway and airplane competition. Some firms leave the industry altogether, while net investment is largely motivated by changes in technology (rather than demand) as well as government regulations concerning service. Firms in the industry are concerned with survival rather than growth. The remaining firms are typically reluctant, or may find it difficult, to acquire capital from external sources and some of the profits may be ploughed back into the firms partly for the purpose of staying in business. ${ }^{12}$

\footnotetext{
${ }^{11}$ The model could be rewritten to allow for planned excess capacity as advocated by Chenery [3]. There is no way, however, of statistically distinguishing between our model and a Chenery-type model unless we have an independent estimate of the coefficient of planned capacity utilization.

${ }^{12}$ This statement is not to imply that railroad firms are not capable of finding external finance in reasonably mobile equipment in times of prosperity, or that they do not invest some of their profits in other industries. Our concern here is merely to emphasize the importance of internal financing in a declining industry. See [6, p. 90].
}

Under these circumstances, levels or changes in output and profitability are largely irrelevant for investment decisions because they have very little relation to the long-run prospects of the industry. The stock-adjustment model would appear to be less applicable when the size of the total stock of fixed capital is near the "saturation" level. Net investment will be carried out largely as a result of replacing worn out equipment by new, technologically superior equipment. Any increase in the size of capital stock is associated with a decline in its average "age," and diminishes opportunities for replacement and thus for new investment. ${ }^{13}$ The financial situation of firms will now become relevant since the firm's earning level is the major source of finance. The level of past profits thus assumes a new role. Instead of being an indicator of future profitability, profits now become an indicator of the availability of funds. A feasible model describing the investment behavior at this stage of the industry's life-cycle might then be

$$
I_{t}=\gamma_{0}+\gamma_{1} K_{t-1}+\gamma_{2} \pi_{t-1}^{* *}+u_{t},
$$

where $\pi^{* *}$ equals net income (including nonoperating income). This model includes net income rather than net operating income since income from all sources is relevant when availability of finance - as distinct from a profitability measure - becomes crucial. The hypothesized change in lag from two years to one year can be explained both by the increased efficiency of communications, management and capital market transactions and by the secular decline in the importance of railroad investment of longer gestation.

\section{Empirical Results}

The tests of the hypotheses described in the previous section have been carried out by obtaining least squares estimates of the regression coefficients and their standard errors. The sources of the data are given in the appendix. The results are presented below.

Klein's Models ${ }^{14}$

Period of adolescence, 1872-1895:

$$
\begin{aligned}
& I_{t}^{G}=201+2.63 \pi_{t-1}+87.15 i_{t-1} \\
& (1129)(0.87) \quad(119.50)
\end{aligned}
$$




$$
\begin{aligned}
& -0.20 K_{t-1}+\hat{u}_{t}, R^{2}=0.455 \\
& (0.06) \\
I_{t}^{G}= & -2053+4.39 \pi_{t-1}+67.33 i_{t-1} \\
& (1095)(0.85) \quad(\mathrm{K} 1) \\
- & 0.33 K_{t-1}+52.17 q_{t-1}+\hat{u}_{t}, R^{2}=0.675 \\
& (0.06) \quad(14.56)
\end{aligned}
$$

Period of maturity, 1896-1914:

$$
\begin{gathered}
I_{t}^{G}=-4276+2.11 \pi_{t-1}+467.70 i_{t-1} \\
(1741)(0.47) \quad(448.90) \\
-0.013 K_{t-1}+\hat{u}_{t}, R^{2}=0.767 ; \\
\quad(0.047) \\
I_{t}^{G}=-1420+0.47 \pi_{t-1}+90.17 i_{t-1} \\
\quad(2029)(0.86)(437.80) \\
-0.107 K_{t-1}+56.55 q_{t-1}+\hat{u}_{t}, \\
(0.060) \quad(25.64) \\
R^{2}=0.824 .
\end{gathered}
$$

Period of senility, 1922-1941:

$$
\begin{aligned}
I_{t}^{G}= & 3952+1.06 \pi_{t-1}+71.39 i_{t-1} \\
& (611)(0.10) \quad(33.16) \\
- & 0.22 K_{t-1}+\hat{u}_{t}, R^{2}=0.908 ; \\
& (0.03) \\
I_{t}^{G}= & 3281+0.97 \pi_{t-1}+59.58 i_{t-1} \\
& (920)(0.13) \quad(35.35) \\
- & 0.20 K_{t-1}+3.86 q_{t-1}+\hat{u}_{t}, R^{2}=0.913 . \\
& (0.03) \quad(3.97)
\end{aligned}
$$

$I^{G}=$ gross investment deflated by $q$ (millions of dollars),

$\pi=$ net operating income including depreciation, deflated by $q$ (millions of dollars),

$i=$ railroad bond yields (percentages),

$K=$ capital stock deflated by $q$ (millions of dollars), and

$q=$ railroad construction cost index, $1929=$ 100.

Klein's own estimates were based on data for the period 1922-1941 and both models were found to be satisfactory. The same conclusion cannot be drawn if the models are re-estimated on the basis of Ulmer's data. The most significant change is in the sign of the coefficient attached to the bond yields variable which now becomes positive - a result which is clearly

yield variable without lag but indicated that a lag of one year could have been used with equal justification and that, in fact, the estimate was not materially affected. unacceptable on theoretical grounds. ${ }^{15}$ An additional conflict arises with the coefficient of $q_{t-1}$ which becomes positive, although not significant.

The application of Klein's models to the early and middle periods also gives unsatisfactory results. The coefficient of the bond yield variable is not significantly different from zero and, furthermore, it appears to be persistently positive. ${ }^{16}$ In addition, a test for the presence of autocorrelation indicated that in both periods disturbances in the regression equations were most probably autocorrelated. If Ulmer's data are reasonably reliable, then it is obvious that Klein's models do not stand up to more extensive examination. They are unsuccessful not only in explaining investment behavior in the earlier periods, but also in producing sensible results for the period for which they were designed.

Let us now consider the empirical results regarding the stage-of-growth models developed in the preceding section of this paper.

Stage-of-Growth Models

Period of adolescence, 1873-1895:

$$
\begin{aligned}
I_{t}^{N} & =697+1.03 X_{t-2}-0.24 K_{t-2} \\
& (382)(0.27) \quad(0.05) \\
& +278.3\left(\pi^{*} / K\right)_{t-2}+2.00\left(\pi_{t-1}^{*}-\pi_{t-2}^{*}\right) \\
& (41.6) \\
+ & \hat{u}_{t}, R^{2}=0.807 .
\end{aligned}
$$

Period of Maturity, 1896-1914:

$$
\begin{aligned}
& I_{t}^{N}=778+0.42 X_{t-2}-0.10 K_{t-2}+\hat{u}_{t}, \\
& \text { (481) (0.09) } \\
& \text { (0.04) } \\
& R^{2}=0.821 \text {. }
\end{aligned}
$$

Period of senility, 1922-1941:

$$
\begin{aligned}
& I_{t}^{N}=3344-0.16 K_{t-1}+0.71 \pi_{t-1}^{* *}+\hat{u}_{t}, \\
& \text { (614) (0.03) } \\
& R^{2}=0.898 \text {. }
\end{aligned}
$$

${ }^{15}$ The bond yield measure used in the re-estimated regression equation differs slightly from that used by Klein. The equations were also re-estimated using the Klein series of bond yields in conjunction with Ulmer's data for the remaining variables but the results did not differ substantially from those given in the text above.

${ }^{16}$ For all three periods, this result appeared consistently. External cost constraints, either measured by bond yields or stock yields, never seem to have had a systematic depressing influence upon aggregate railroad investment, regardless of the industry's stage-of-growth. 
$I^{N}=$ net investment deflated by $q$ (millions of dollars),

$X=$ railroad operating revenue deflated by $q$ (millions of dollars),

$K=$ capital stock deflated by $q$ (millions of dollars),

$\pi^{*}=$ net operating income excluding depreciation deflated by $q$ (millions of dollars),

$\pi^{* *}=$ net income deflated by $q$ (millions of dollars), and

$\pi^{*} / K$ in (SG 1 ) is given in percentage rates.

The statistical results of the stage-of-growth analysis of investment behavior are satisfactory. A Durbin-Watson test revealed that autocorrelation of disturbances was likely to be present only in the middle period, and the standard errors of the coefficients given in (SG 2) are corrected to allow for this. ${ }^{17}$ Even after this adjustment, all three stage-of-growth models have statistically significant coefficients of the expected sign, and the goodness of fit is reasonably high. It might be noted here that we used each of these three models to explain investment behavior in each period and found, as predicted, that they had poor explanatory power when removed from the life-cycle environment for which they were developed. It would appear that the use of different investment models for different periods of industry development is clearly superior to the uniform model approach.

The investment relation for the early development stage indicates that autonomous investment in the railroads was probably negligible during the 1870's, 1880's, and early 1890's. The coefficients of the stock-adjustment factors give an estimated "normal" capital-output ratio of 4.36 and a "reaction" coefficient of about $0.24 .{ }^{18}$ Furthermore, both profitability indicators, presumably showing their influence on

\footnotetext{
${ }^{17}$ For the development of the correction formula see, for example, Goldberger [11, pp. 236-243].

${ }^{18}$ If there were some planned excess capacity and Chenery's modification of the stock-adjustment model applied, the "normal" capital-output ratio would be somewhat lower and the "reaction" coefficient somewhat higher than the quoted figures. In any case the result appears to be consistent with the findings of other research workers, e.g., Kuh [18] or Koyck [17]. Kuh in [18, p. 334] writes, "Perhaps the principal explanation for this low magnitude in estimated reaction coefficients ... is the pervasive uncertainty of manufacturers about the expected level of capacity utilization."
}

investment by new firms, clearly appear to be important explanatory variables. The relative importance of the two sources of variation in investment - the stock-adjustment and the expected profitability measures - should be of some interest. We have evaluated this by taking into account the magnitudes of the coefficients as well as the variation in the respective explanatory variables. Apart from the changes in investment due to joint variation, we found that changes in profitability measures were somewhat more important in affecting variation in railroad investment than changes in the stock-adjustment variables. ${ }^{19}$

As a matter of interest, we have also fitted a relationship similar to (SG 1) but one in which the stock adjustment variables were replaced by a single variable $\left(X_{t-1}-X_{t-2}\right)$, a simple accelerator principle. Whether we tested the simple accelerator by itself or combined with profitability indicators, the results were poor. The goodness of fit was much lower than that of (SG 1) and, more important, the acceleration coefficient was smaller than its standard error.

The regression equation relating to the stage of mature growth reveals that a very high proportion of the variation in aggregate railroad investment can be explained by stock-adjustment factors alone. Autonomous investment is again found to be probably negligible. The estimate of the "normal" capital-output ratio for this period is 4.08 while the "reaction" coefficient is considerably lower than that of the earlier period. ${ }^{20}$ The numerical values of the coefficients were little affected by changing the

\footnotetext{
${ }^{10}$ This result was mildly surprising. Our theoretical discussion in the preceding section suggested that the profitability measures would have assumed greater relative importance in the pre-1870's when the industry could be described as being dominated more by new firms than by old ones. The relative importance of the two sets of factors can be established by comparing the following two magnitudes:

Variation due to stock-adjustment

$=\left[(1.026)^{2} \operatorname{Var}\left(X_{t-2}\right)+(0.235)^{2} \operatorname{Var}\left(K_{t-2}\right)\right.$

$\left.-2(1.026)(0.235) \operatorname{Cov}\left(X_{t-2}, K_{t-2}\right)\right]^{1 / 2}=145.32$.

Variation due to profitability$$
=\left[(1.995)^{2} \operatorname{Var}\left(\Delta \pi_{t-1}^{*}\right)+(278.3)^{2} \operatorname{Var}\left(\frac{\pi^{*}}{K_{t-2}}\right)\right.
$$$$
\left.+2(1.995)(278.3) \operatorname{Cov}\left(\Delta \pi_{t-1}^{*} ; \frac{\pi^{*}}{K_{t-2}}\right)\right]^{1 / 2}=219.11
$$

${ }^{20}$ Again, this result is consistent with that of Koyck [17] who found a decline in the reaction coefficient in response to a decline in the long-run expected trend rate of growth.
} 
lag from two years to one, but the statistical fit was poorer with the shorter lag and the disturbances appeared to be much more highly autocorrelated. The simple acceleration principle again produced very poor results.

For the period of senility, 1922-1941, the levels of last year's profits and last year's capital stock appear to produce a good explanation of investment variation. Along with some positive autonomous investment, it seems that on the average every unit increase in the capital stock resulted in a 0.16 unit decrease in net investment in the following year while about 71 per cent of each increase in net income was re-invested. An analysis of the relative importance of $K_{t-1}$ and $\pi_{t-1}^{* *}$ reveals that changes in net income were more important sources of variation in investment than changes in the size of capital stock. ${ }^{21}$ When either bond or stock yields were included, their coefficients were not significant.

\section{Concluding Summary}

This paper has attempted to explain investment behavior in the American railroads over the period 1872-1941. A theoretical argument has been made for expecting different patterns of investment behavior to be associated with different positions in the industry's life-cycle. Consequently, the entire period 1872-1941 has been divided into a stage of adolescence from 1872 to 1895 , a stage of maturity from 1896 to the first World War, and a stage of senility for the inter-war period. This division has been justified by the changes of basic industry characteristics in each of the periods of railroad development.

It has been found that a "single model" approach to explain investment behavior breaks down when applied to differing stages of railroad development. On the other hand, the stage-of-growth models have produced very satisfactory results. In particular, we found that in the first two periods - the periods of adolescence and of maturity - a significant proportion of the variation in investment could be explained by the "stock-adjustment prin-

${ }^{21}$ Variation due to changes in capital stock

$=(-0.156)$ standard deviation of $K_{t-1}=-125.70$, while variation due to changes in net income

$=(0.706)$ standard deviation of $\pi_{t-1}^{* *}=237.71$. ciple." In the first period, the stock adjustment model was extended to explain the somewhat different investment behavior of firms developing in new regions. In the period of maturity, in which the industry raised its barriers to new entry and the older firms increased their oligopolistic control, the stock-adjustment principle alone produced a very good explanation. In both of these periods, the simple acceleration principle proved to be a poor substitute for the stock-adjustment model. Finally, in the inter-war period of stagnation and decline of the railroad industry the explanation of investment behavior was traced to the influence of changes in internal funds and in size of capital stock, the former being more influential than the latter. At no stage in the industry's lifecycle were external costs of securing capital of importance in constraining aggregate railroad investment.

The stage-of-growth approach to investment analysis advanced in this paper can be represented as a logical extension of the notion that coefficients of investment models would be nonlinear with respect to the business cycle. ${ }^{22}$ When growth cycles are considered, the pertinent investment models themselves can be expected to change. All of this suggests considerable potential for the life-cycle approach as contrasted to models which disregard the stage of industry development. Presumably, the analysis could be readily adapted to study other industries for which we now have time-series data.

\section{REFERENCES}

[1] M. Abramovitz, "The Nature and Significance of Kuznets Cycles," Economic Development and Cultural Change (Apr. 1961), 225-248.

[2] A. C. Bolino, The Development of the American Economy (Columbus: Merrill, 1961).

[3] H. B. Chenery, "Overcapacity and the Acceleration Principle," Econometrica, 20 (Jan. 1952), 1-28.

[4] T. C. Cochran, Railroad Leaders, 1845-1890: The Business Mind in Action (Cambridge, Mass.: Harvard University Press, 1953).

[5] P. H. Cootner, "The Role of the Railroads in United States Economic Growth," Journal of Economic History, 23 (Dec. 1963), 477-521.

${ }^{22} \mathrm{See}$, for example, the more recent works of Kuh and Meyer $[19,18]$. For an earlier approach see, for example, [13] and [7]. 
[6] J. S. Duesenberry, Business Cycles and Economic Growth (New York: McGraw-Hill, 1958).

[7] R. Eisner, "A Distributed Lag Investment Function," Econometrica, 28 (Jan. 1960), 1-29.

[8] R. Eisner and R. H. Strotz, "Determinants of Business Investment," in Commission on Money and Credit, Impacts of Monetary Policy (Englewood Cliffs, New Jersey: PrenticeHall, 1963).

[9] R. Fels, American Business Cycles, 1865-1897 (Chapel Hill: University of North Carolina Press, 1959).

[10] A. Fishlow, "Technological Change in the Railroad Sector, 1840-1910," (National Bureau of Economic Research, Conference on Research in Income and Wealth, Sept. 4-5, 1963 mimeo).

[11] A. S. Goldberger, Econometric Theory (New York: John Wiley, 1964).

[12] C. Goodrich, Government Promotion of American Canals and Railroads, 1800-1890 (New York: Columbia University Press, 1960).

[13] R. M. Goodwin, "Secular and Cyclical Aspects of the Multiplier and the Accelerator," in Income, Employment, and Public Policy: Essays in Honor of Alvin H. Hansen (New York: W. W. Norton, 1948).

[14] Interstate Commerce Commission, Bureau of
Transport Economics and Statistics, Postwar Capital Expenditures of the Railroads (Washington, March 1947).

[15] - Bureau of Valuation, Railroad Construction Indices (Washington, August 1, 1942).

[16] L. R. Klein, "Studies in Investment Behavior," in Universities - National Bureau Committee of Economic Research, Conference on Business Cycles (New York: National Bureau of Economic Research, 1951).

[17] L. M. Koyck, Distributed Lags and Investment Analysis (Amsterdam, 1954).

[18] E. Kuh, Capital Stock Growth: A Micro-Econometric Approach (Amsterdam, 1963).

[19] E. Kuh and J. R. Meyer, "Investment, Liquidity, and Monetary Policy," in Commission on Money and Credit, Impacts of Monetary Policy (Englewood Cliffs, New Jersey, 1963).

[20] J. Tinbergen, Statistical Testing of BusinessCycle Theories, I, A Method and its Application to Investment Activity (Geneva, 1939).

[21] M. J. Ulmer, Capital in Transportation, Communications, and Public Utilities: Its Formation and Financing (Princeton, 1960).

[22] J. G. Williamson, American Growth and the Balance of Payments: A Study of the Long Swing (Chapel Hill, 1964).

\section{APPENDIX}

\section{Sources of Data ${ }^{23}$}

$I^{N}:$ 1870-1941, [27, Table C-1, Col. (8), pp. 256257].

$I^{G}:$ 1870-1941, [27, Table C-1, Col. (4), pp. 256257].

$K$ : 1869-1941, [27, Table C-1, Col. (2), pp. 256257].

$X:$ 1880-1941, [27, Table I-13, Col. (2), pp. 472473].

1870-1879, extrapolation using Ulmer [27, Table I-13, Col. (2), pp. 472-473] and Poor's data in Historical Statistics of the United States: Colonial Times to 1957 (Washington: U.S. Government Printing Office, 1960), Q38, p. 428 after the latter had been deflated by $q$ and where 1870 entry = January 1, 1871 .

$q: \quad 1869-1941$, [27, Table C-11, Col. (12), pp. 274-

${ }^{23}$ Due to limitations of space it is not possible to give a full description of the time series used in obtaining the empirical results. This information will be made available upon request. For further identification of the variables listed above, the reader may consult the text.
277]. Combined index of cost of road and equipment.

$i$ : 1871-1936: Macauly's unadjusted index of railroad bond yields in Historical Statistics of the United States: Colonial Times to 1957, X 332, p. 656.

1936-1941: Moody's average yield on new railroad bonds linked to above. Moody's Railroads, 1946, Moody's Investor Service, p. a 49.

$\pi$ : 1871-1941: $\pi=$ net operating income plus depreciation deflated by $q$. Net operating income comes from M. Abramovitz's worksheets where Poor's data (Historical Statistics of the United States: Colonial Times to 1957, Q40 and SQ $110+112$, p. 110) has been adjusted to calendar years. Depreciation has been taken from [27, Table C-12, Col. (7), pp. 278-279] where 1869 entry $=$ January 1,1870 .

$\pi^{*}$ : 1871-1941: Net operating income deflated by $q$.

$\pi^{* *}$ : 1920-1941: Net income deflated by $q$. Net income comes from Historical Statistics of the United States: Colonial Times to 1957, Q 113, p. 434. 